\title{
Improving collection efforts to avoid loss of biodiversity: lessons from comprehensive sampling of lycophytes and ferns in the subtropical Atlantic Forest
}

\author{
André Luis de Gasper ${ }^{12 *}$, Pedro V. Eisenlohr ${ }^{3}$ and Alexandre Salino²
}

Received: November 9, 2015

Accepted: February 2, 2016

\begin{abstract}
Estimating species richness with herbarium data and new collections allows us to understand the distribution of diversity. We investigated the accuracy of lycophyte and fern sampling along a vegetation gradient in the subtropical Atlantic Forest in southern Brazil. We compiled lycophyte and fern collection metadata and estimated species richness and assessed sampling accuracy for sixty 50 x $50 \mathrm{~km}$ units using ACE, Chao 1, Chao 2, Jackknife 1 and Jackknife 2 estimators. We compiled data for 12,779 fern specimens of 441 species, 67 of which were sampled in only one unit (singletons) and 35 in two units (duplicates). Of the 60 units examined, only 11 had observed values that were above $70 \%$ of their estimated values, and 14 had observed levels between $65-70 \%$ of the estimated values, meaning that 35 units had a sampling accuracy of less than $65 \%$. In spite of the long history of lycophyte and fern collecting in the study area, there remain units with a lower than expected sampling accuracy for a subtropical forest. This finding indicates that a sizeable collection effort is needed in order to discover the actual distribution of species before the effects of fragmentation and deforestation become permanent.
\end{abstract}

Keywords: botanical collections, estimators, hotspot, pteridophyte, southern Brazil, species richness estimates

\section{Introduction}

The worldwide interest in biodiversity issues has been unhesitatingly growing (Lughadha 2004; Lewinsohn \& Prado 2005; Condon et al. 2008; Butchart et al. 2010; Barbault 2011; May 2011), manifested especially in the compilation of large surveys and lists of species (see Zuloaga et al. 2008; Forzza et al. 2012). However, most of the datasets are still spatially and taxonomically biased (Hortal et al. 2008; Sastre \& Lobo 2009), especially when different sources are used, such as botanical collections. Nevertheless, these collections comprise key tools for ecological studies (Sánchez-Fernández et al. 2008; Maldonado et al. 2015), especially where the original vegetation still exists. Large on-line databases on biological diversity such as speciesLink (CRIA 2015) and The Global Biodiversity Information Facility (GBIF) can contribute to further analysis such as species modeling and geographical distribution (Feeley \& Silman 2011) because they host data from various collections. In addition to the large amount of data currently available, both scrutiny and validation by taxonomic experts need to be done to ensure data quality (Maldonado et al. 2015).

Furthermore, these tools can help to identify insufficient sampling and gaps (Pyke \& Ehrlich 2010; Maldonado et al.

\footnotetext{
${ }^{1}$ Departamento de Ciências Naturais, Universidade Regional de Blumenau, Rua Antônio da Veiga, 140, T-226, 89012-900, Blumenau, SC, Brazil

${ }^{2}$ Departamento de Botânica, Universidade Federal de Minas Gerais, P.O. Box 486, 30123-970, Belo Horizonte, MG, Brazil

${ }^{3}$ Faculdade de Ciências Biológicas e Agrárias, Campus de Alta Floresta, Universidade do Estado de Mato Grosso, P.O. Box 324, 78580-000,

Alta Floresta, MT, Brazil

* Corresponding author: algasper@gmail.com
} 
2015), especially in tropical areas and biodiversity hotspots. Deforestation (Pandit et al. 2007), forest fragmentation (Rodríguez-Loinaz et al. 2011; Silva et al. 2014), human disturbances (Murphy \& Romanuk 2014), undiscovered species (Tedesco et al. 2014), and climate changes (Urban 2015) are some of the threats to biodiversity (Kim \& Byrne 2006; Butchart et al. 2010), and all of these threats occur in the Brazilian Atlantic Forest. This biome has critical conservation status (as other hotspots; Sloan et al. 2014), having only $\sim 12 \%$ of the original vegetation cover (Ribeiro et al. 2011), and deforestation continues (Fundação SOS Mata Atlântica \& Instituto Nacional de Pesquisas Espaciais 2009).

In high-diversity regions, such as Brazil, two of the botanical groups that need more attention regarding sampling coverage are the lycophytes and ferns. In the Red Book of the Brazilian Flora (Martinelli \& Moraes 2013), both groups are the most threatened when the estimated number of species in each taxon is considered. Despite this fact, the state of Santa Catarina has a well-known lycophyte and fern flora, as shown by large surveys such as the projects of Flora of Santa Catarina (1967-1984) and the Floristic and Forest Inventory of Santa Catarina (Vibrans et al. 2010; Gasper et al. 2012). However, even with these large projects, many areas were not sampled. The first project has approximately 180 collection points, the second has 597 . Another concern is the time interval between these projects, because during this interval the forest loss increased (Fundação SOS Mata Atlântica \& Instituto Nacional de Pesquisas Espaciais 2009). Because of these kinds of initiatives, and also due its physiognomic gradients, Santa Catarina constitutes an excellent environmental model for investigation of floral distribution and sampling sufficiency (see also Rezende et al. 2014; 2015; Gasper et al. 2015).

Our aim was to analyze the sampling of lycophytes and ferns, evaluating both insufficiently and sufficiently sampled areas in Santa Catarina, Brazil, to discuss efforts for attaining more accurate samplings. We were guided by the following questions: 1) Even when a region was wellstudied, with standardized sampling units, could we see important collection gaps (insufficiencies) for lycophytes and ferns? We addressed this question based on richness estimators, which are powerful tools to check for sampling accuracy (Chiarucci et al. 2003); 2) What are the geographic regions with a more complete sampling effort and what are the ones with inadequate collections? We expected that the coastal region, where Rainforest dominates, would contain the most well-known vegetation, followed by the plateau (Mixed Forest) and western region (Seasonal Forest), because, in spite of major projects conducted statewide, many collections have been made near protected areas and universities, and in the coastal region there is a higher concentration of these institutions. We discuss these issues in light of conservation implications of under-sampling the biodiversity in high-diversity and high-threatened regions.

\section{Materials and methods}

\section{Study area}

The state of Santa Catarina is located in Southern Brazil, between $25^{\circ} 57^{\prime} 41^{\prime \prime}-29^{\circ} 23^{\prime} 55^{\prime \prime}$ S and $48^{\circ} 19^{\prime} 37^{\prime \prime}$

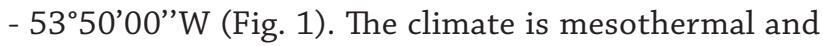
rather humid in the Southern Plateau ( $\mathrm{Cfb}$ according to the Köppen classification) and humid subtropical along the coast and in the Atlantic Slope (Cfa according to the Köppen classification), with very high temperatures (Klein 1984). Nimer (1989) considered the region to be a temperate zone, with high cloud formation and rainfall regimes, the annual rainfall ranging from $1,250 \mathrm{~mm}$ to $2,000 \mathrm{~mm}$. There are two very distinct seasons: cold winter and hot summer (Klein 1984). The first extends from June to August and the second, from December to March.

Santa Catarina is covered by the Subtropical Atlantic Forest and its phytoecological zones are: Seasonal Semideciduous Forest, in the Uruguay River channel; Mixed Forest (Araucaria Forest), on the plateau and in the western region of Santa Catarina; Rainforest as well as the fluvial and marine influence zones towards its coast (Mangrove and Coastal Dwarf Forest, respectively) (IBGE 1992; OliveiraFilho 2009).

\section{Data compilation}

We used the same criteria adopted by Gasper et al. (2015) to delimit the sample units (SU) and compile the database, which had 12,779 lycophyte and fern records in Santa Catarina (Fig. 2), with all units represented by at least five samples. Of the registered species, three did not inform the municipality (Santa Catarina State only indicated) and were removed from the analysis. We prepared the database with the information of collections done in Santa Catarina. The botanical material was deposited in the following herbaria: ASE, B, BHCB, BM, BOTU, CRI, ESA, F, FCAB, FIC, FLOR, FUEL, FURB, G, GH, GUA, HAS, HB, HBR, HCF, HRCB, HSJRP, HUCS, HUEFS, ICN, INPA, IRAI, JOI, JPB, K, LIL, MBM, MO, NY, P, PACA, R, RB, RBR, RJ, S, SP, SPF, UB, UC, UEC, UPBC and US (Thiers 2015), the IFFSC project (Vibrans et al. 2010), the 'Pteridófitas da Mata Atlântica' project (part of the dataset was compiled by Salino \& Almeida 2009) and speciesLink (CRIA 2015). All information on the specimen labels was digitized. Theses and dissertations were used to compare the identifications in the herbaria with the database. Material that could be not checked for accuracy of identification was not considered in our analysis. Herbarium duplicates (same collector and number) were removed in order to avoid overestimates. We constructed two matrices: (i) a matrix with scientific names as well as longitude and latitude coordinates; (ii) a binary matrix (record presence or absence) by sampling 


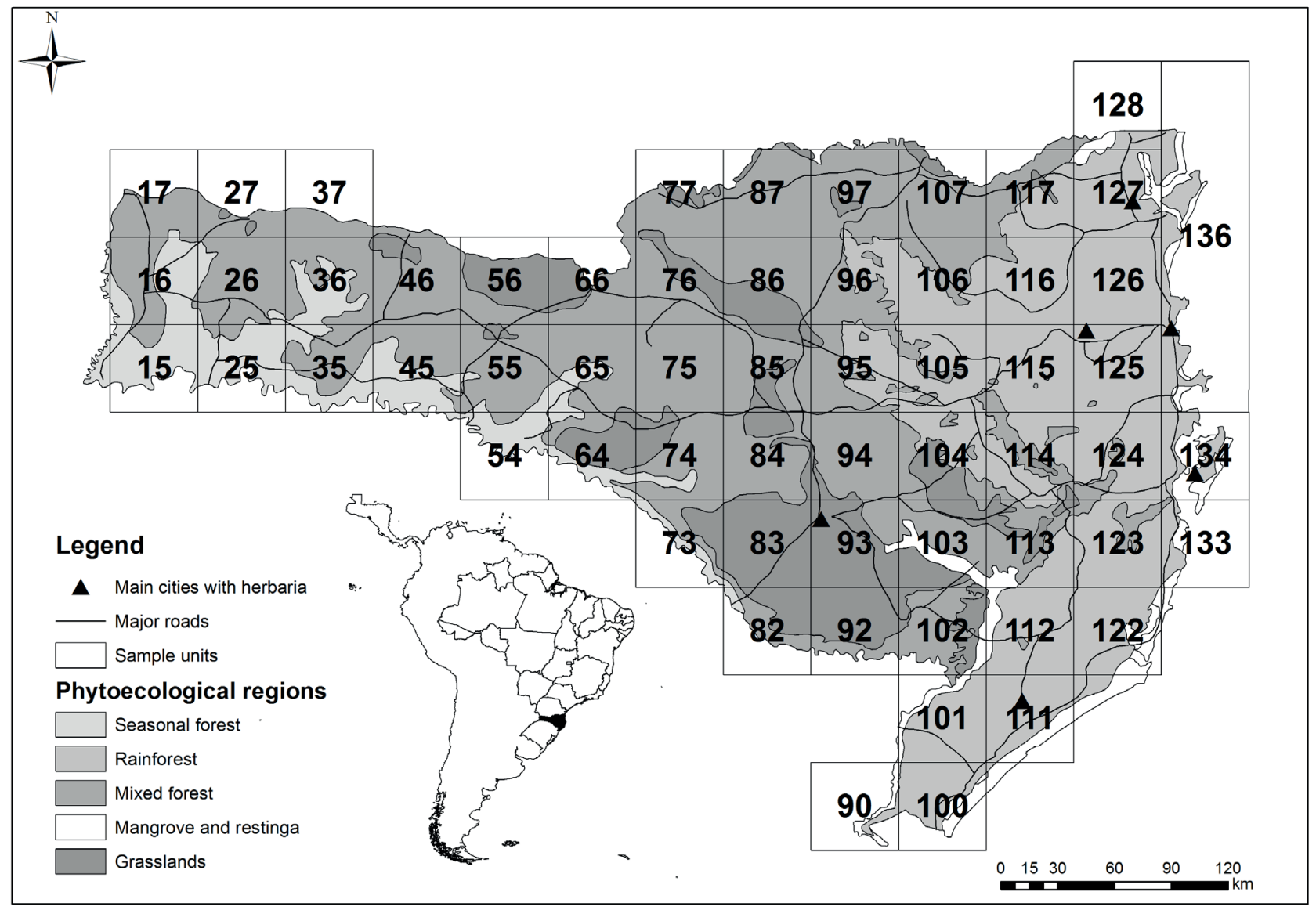

Figure 1. Distribution of sample units (SU) across phytoecologial regions in a sector of the Subtropical Atlantic Forest. Number of $50 \mathrm{x}$ $50 \mathrm{~km}$ sample units in the grid distributed in a sector of the Subtropical Atlantic Forest, generated through Hawth's Tools in ArcGIS 10.

unit. The first matrix was used to map the distribution of specimens and proceed with the grid estimators, and the second was used to estimate sampling effort. The coordinate used was the original one, or when the coordinate was lacking in the samples, we added a coordinate based on the collection locality (using other collections), or based on the municipality coordinates. The municipalities of Santa Catarina are small; thus, when a coordinate was provided, the probability of changing the original SU was reduced.

The layout and analysis maps of sample units were developed using ArcGIS ${ }^{\circledR} 10$ software (ESRI 2011) and estimators grids in DIVA-GIS 7.5 (Hijmans et al. 2005). From the 60 sample units (Fig. 1), we obtained the sample number and the species number using the intersect function of ArcGIS $^{\circledR} 10$.

\section{Data analysis}

We estimated the sampling accuracy with ACE (ACE), Chao 1 (C1), Chao 2 (C2), Jackknife 1 (J1) and Jackknife 2 (J2) non-parametric estimators. These estimators can help in diversity estimates in studies with grids or plots, extrapolating total species richness from an incomplete sample of a biological community (Walther \& Moore 2005), because they use unicates/singletons and duplicates/ doubletons in their equations (Colwell \& Coddington 1994). The Jackknife 1 is based on the presence of uniques in sampling units, defined as the species recorded in only one sampling unit, and Jackknife 2 considers also the duplicates, i.e., species that occur in exactly two samples (Chiarucci et al. 2003). The Chao 1 considers both singletons and doubletons, i.e., the number of species that have exactly one and two individuals (here, the number of records within a sampling unit), respectively, and Chao 2 considers both uniques and duplicates (Chao 1984; Chao \& Lee 1992; Colwell \& Coddington 1994). ACE is an abundance-based coverage estimator that considers species with 1-10 individuals (in our case, collections) plus the abundant species ( $>10$ individuals) (Chao \& Lee 1992; Colwell \& Coddington 1994). All estimators assume that the higher the number of species poorly represented, the more likely is the occurrence of some other species in the area that are not represented at all in the data set.

We calculated the estimators for each SU independently, using DIVA-GIS (Hijmans et al. 2005) and a shapefile. Note that DIVA-GIS software considers as abundance data the number of records within each sampling unit, although the original matrix was based only on presence/absence records. 


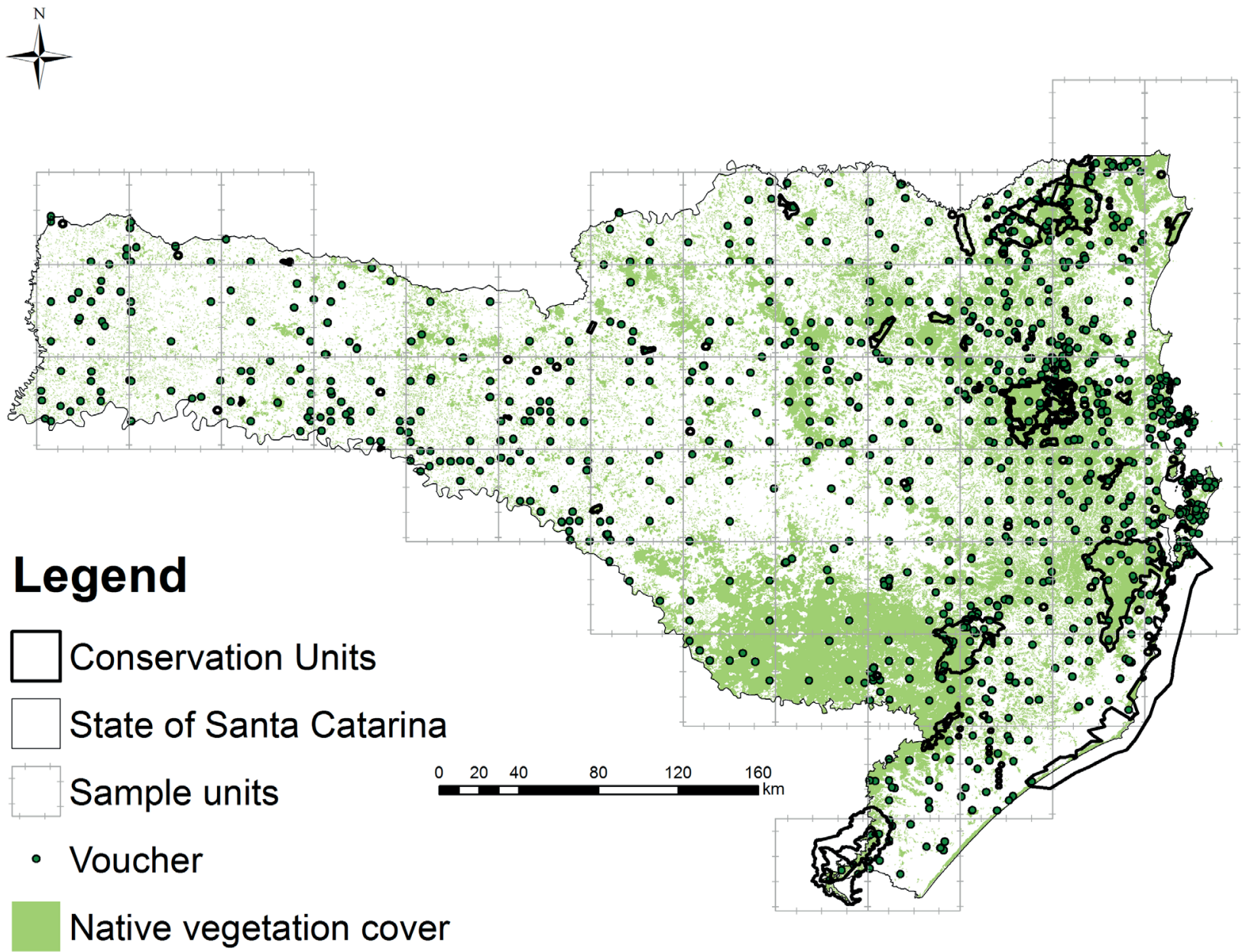

Figure 2. Records of lycophytes and ferns in a sector of the Subtropical Atlantic Forest.

For all studied areas we used EstimateS 9.1 (Colwell 2013). We considered a SU to be well-sampled when we found at least $60 \%$ of the estimated value compared to the observed value, according to the aforementioned estimators (near to the value recommended by Heck Jr et al. 1975 and JiménezValverde \& Hortal 2003). This can be justified because when the records performed in these 20 SUs were discarded, none of the species was removed from the general list. Hence, no species recorded in these $20 \mathrm{SU}$ was different when compared with the other 40 .

\section{Results}

Considering the entire state of Santa Catarina, the estimators showed values between 466 and 535 species (Tab. 1). For some SU, the observed values reached $70 \%$ of the estimated values, except for J2, where no SU had more than $67 \%$ (Fig. 3, Tab. 1). Considering the $60 \%$ cut-off value, we found a value between four and $27 \mathrm{SU}$ well-sampled (Tab. 2). The western region, where Seasonal Forest predominates, had lower richness and a poor sampling accuracy, which was almost achieved in two other SU (15 and 16). This also occurred in Santa Catarina plateau (Mixed Forest) and ecotones with grasslands. The coastal region, where Rainforest predominates, showed the highest richness values. The coastal region also had the highest number of registered collections (Fig. 2).

Eleven out of 60 SU tested showed values above $70 \%$ in relation to the estimated richness values (using Jackknife 1 ), and 14 other SU had levels between 65-70\%. In addition, 15 SU had values between $60-65 \%$; $67 \%$ of the SU had values above $60 \%$, which was the cutoff used here to consider a SU accurately sampled. Twenty SU had an estimated value below $60 \%$ in relation to the observed one. Among the minimum values of five and maximum of 248 species recorded in the SU, the values estimated with Jackknife 1 were nine and 307 species, respectively. Twenty-six SU had species estimated at numbers higher than 100 , all of them located near the coastal zone (Tab. 1). Jackknife 2 did not exhibit any area with more than $70 \%$ of the observed value (compared to the predicted value), while each of the other indices exhibited more than 10 areas with such characteristics (Fig. 4, Tab. 2). 

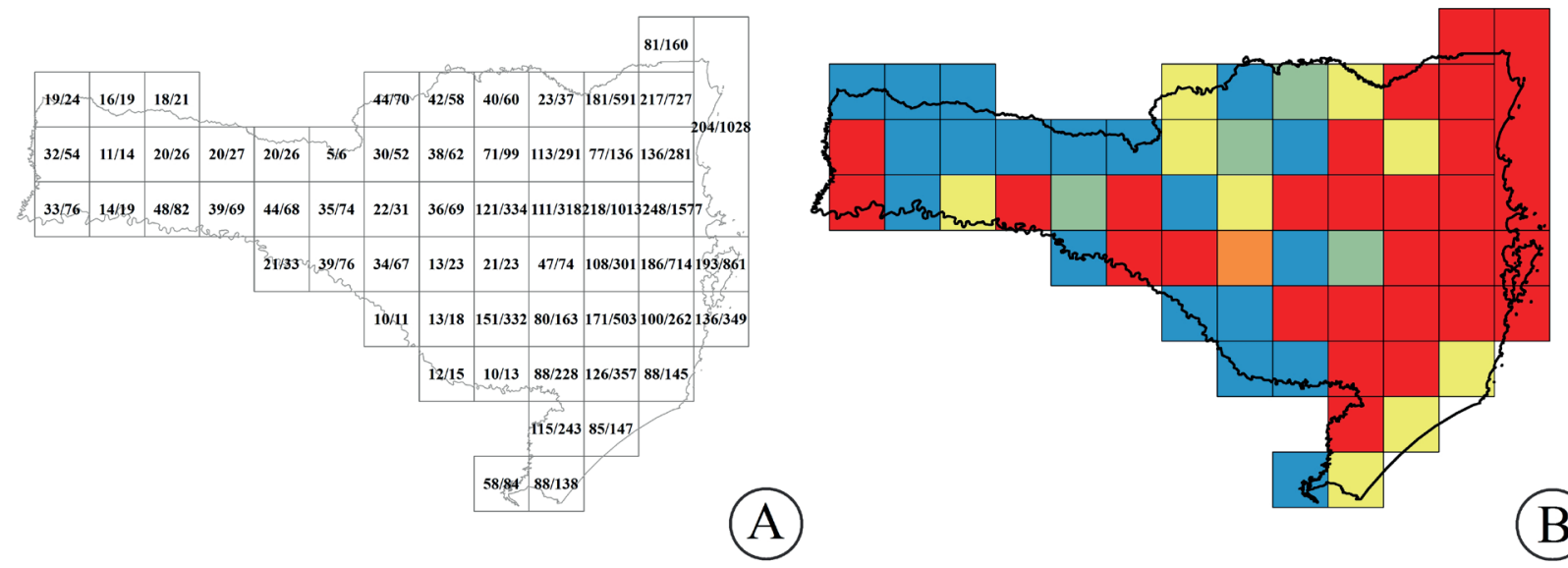

(A)

(B)
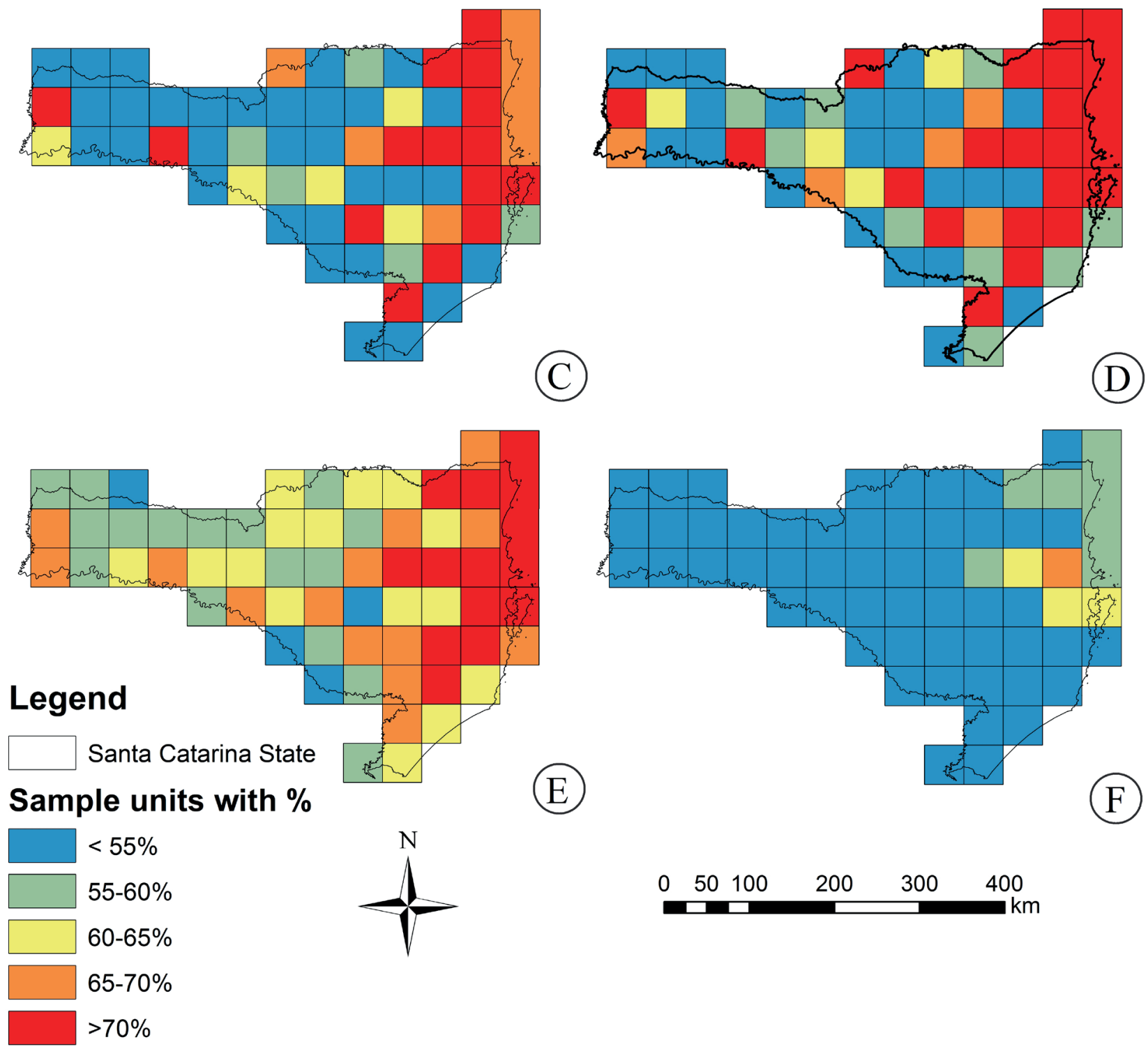

Figure 3. Number of species found in each $50 \times 50 \mathrm{~km}$ sample unit in a sector of the Subtropical Atlantic Forest (A). The maximum value was 248 species, with 1,578 records. The colors in the SU represent classes of species richness values estimated with: B) ACE, C) Chao 1, D) Chao 2, E) Jackknife 1, and F) Jackknife 2. The ratio of the number of sampled/species is shown. Please see the PDF version for color reference. 
Table 1. Estimated richness obtained for each sample unit in a sector of the Subtropical Atlantic Forest using different estimate methods and percentage values. Collection number (COL), ACE (ACE), Chao 1 (C1), Chao 2 (C2), Jackknife 1 (J1) and Jackknife 2 (J2). Sample units (SU), records (COL), species number (S).

\begin{tabular}{|c|c|c|c|c|c|c|c|c|c|c|c|c|}
\hline SU & COL & $\mathbf{S}$ & ACE & ACE\% & C1 & $\mathrm{C} 1 \%$ & $\mathrm{C2}$ & $\mathrm{C} 2 \%$ & $\mathrm{J1}$ & $\mathbf{J 1} \%$ & $\mathrm{J2}$ & $\mathrm{J} 2 \%$ \\
\hline 15 & 76 & 33 & 42 & 78.6 & 51 & 64.7 & 48 & 68.8 & 65 & 50.77 & 49 & 67.3 \\
\hline 16 & 54 & 32 & 45 & 71.1 & 43 & 74.4 & 41 & 78.0 & 64 & 50.00 & 48 & 66.7 \\
\hline 17 & 24 & 19 & 51 & 37.3 & 57 & 33.3 & 46 & 41.3 & 49 & 38.78 & 34 & 55.9 \\
\hline 25 & 19 & 14 & 30 & 46.7 & 31 & 45.2 & 26 & 53.8 & 34 & 41.18 & 24 & 58.3 \\
\hline 26 & 14 & 11 & 26 & 42.3 & 22 & 50.0 & 18 & 61.1 & 27 & 40.74 & 19 & 57.9 \\
\hline 27 & 19 & 16 & 51 & 31.4 & 44 & 36.4 & 36 & 44.4 & 42 & 38.10 & 29 & 55.2 \\
\hline 35 & 82 & 48 & 79 & 60.8 & 133 & 36.1 & 119 & 40.3 & 112 & 42.86 & 80 & 60.0 \\
\hline 36 & 26 & 20 & 47 & 42.6 & 48 & 41.7 & 41 & 48.8 & 50 & 40.00 & 35 & 57.1 \\
\hline 37 & 21 & 18 & 63 & 28.6 & 56 & 32.1 & 45 & 40.0 & 48 & 37.50 & 33 & 54.5 \\
\hline 45 & 69 & 39 & 55 & 70.9 & 54 & 72.2 & 53 & 73.6 & 79 & 49.37 & 59 & 66.1 \\
\hline 46 & 27 & 20 & 42 & 47.6 & 40 & 50.0 & 35 & 57.1 & 48 & 41.67 & 34 & 58.8 \\
\hline 54 & 33 & 21 & 39 & 53.8 & 59 & 35.6 & 48 & 43.8 & 51 & 41.18 & 36 & 58.3 \\
\hline 55 & 68 & 44 & 75 & 58.7 & 83 & 53.0 & 78 & 56.4 & 100 & 44.00 & 72 & 61.1 \\
\hline 56 & 26 & 20 & 52 & 38.5 & 84 & 23.8 & 61 & 32.8 & 52 & 38.46 & 36 & 55.6 \\
\hline 64 & 76 & 39 & 54 & 72.2 & 61 & 63.9 & 58 & 67.2 & 81 & 48.15 & 60 & 65.0 \\
\hline 65 & 74 & 35 & 47 & 74.5 & 61 & 57.4 & 57 & 61.4 & 73 & 47.95 & 54 & 64.8 \\
\hline 66 & 6 & 5 & 15 & 33.3 & 13 & 38.5 & 9 & 55.6 & 13 & 38.46 & 9 & 55.6 \\
\hline 73 & 11 & 10 & 55 & 18.2 & 51 & 19.6 & 29 & 34.5 & 28 & 35.71 & 19 & 52.6 \\
\hline 74 & 67 & 34 & 47 & 72.3 & 60 & 56.7 & 56 & 60.7 & 72 & 47.22 & 53 & 64.2 \\
\hline 75 & 31 & 22 & 49 & 44.9 & 70 & 31.4 & 57 & 38.6 & 56 & 39.29 & 39 & 56.4 \\
\hline 76 & 52 & 30 & 47 & 63.8 & 90 & 33.3 & 73 & 41.1 & 68 & 44.12 & 49 & 61.2 \\
\hline 77 & 70 & 44 & 68 & 64.7 & 65 & 67.7 & 63 & 69.8 & 94 & 46.81 & 69 & 63.8 \\
\hline 82 & 15 & 12 & 36 & 33.3 & 62 & 19.4 & 36 & 33.3 & 32 & 37.50 & 22 & 54.5 \\
\hline 83 & 18 & 13 & 26 & 50.0 & 27 & 48.1 & 22 & 59.1 & 31 & 41.94 & 22 & 59.1 \\
\hline 84 & 23 & 13 & 19 & 68.4 & 21 & 61.9 & 18 & 72.2 & 27 & 48.15 & 20 & 65.0 \\
\hline 85 & 69 & 36 & 56 & 64.3 & 192 & 18.8 & 137 & 26.3 & 86 & 41.86 & 61 & 59.0 \\
\hline 86 & 62 & 38 & 64 & 59.4 & 83 & 45.8 & 76 & 50.0 & 88 & 43.18 & 63 & 60.3 \\
\hline 87 & 58 & 42 & 90 & 46.7 & 102 & 41.2 & 94 & 44.7 & 104 & 40.38 & 73 & 57.5 \\
\hline 90 & 84 & 58 & 108 & 53.7 & 121 & 47.9 & 115 & 50.4 & 136 & 42.65 & 97 & 59.8 \\
\hline 92 & 13 & 10 & 36 & 27.8 & 42 & 23.8 & 25 & 40.0 & 26 & 38.46 & 18 & 55.6 \\
\hline 93 & 332 & 151 & 188 & 80.3 & 201 & 75.1 & 199 & 75.9 & 280 & 53.93 & 216 & 69.9 \\
\hline 94 & 23 & 21 & 121 & 17.4 & 111 & 18.9 & 79 & 26.6 & 59 & 35.59 & 40 & 52.5 \\
\hline 95 & 334 & 121 & 143 & 84.6 & 180 & 67.2 & 176 & 68.8 & 225 & 53.78 & 173 & 69.9 \\
\hline 96 & 99 & 71 & 153 & 46.4 & 199 & 35.7 & 186 & 38.2 & 177 & 40.11 & 124 & 57.3 \\
\hline 97 & 60 & 40 & 69 & 58.0 & 68 & 58.8 & 65 & 61.5 & 90 & 44.44 & 65 & 61.5 \\
\hline 100 & 138 & 88 & 146 & 60.3 & 160 & 55.0 & 156 & 56.4 & 198 & 44.44 & 143 & 61.5 \\
\hline
\end{tabular}


Table 1. Cont.

\begin{tabular}{|c|c|c|c|c|c|c|c|c|c|c|c|c|}
\hline SU & $\mathrm{COL}$ & $\mathbf{S}$ & ACE & ACE $\%$ & C1 & C1\% & C2 & C2\% & $\mathrm{J1}$ & $\mathrm{J} 1 \%$ & $\mathrm{~J} 2$ & $\mathrm{~J} 2 \%$ \\
\hline 101 & 243 & 115 & 149 & 77.2 & 163 & 70.6 & 160 & 71.9 & 227 & 50.66 & 171 & 67.3 \\
\hline 102 & 228 & 88 & 109 & 80.7 & 153 & 57.5 & 147 & 59.9 & 176 & 50.00 & 132 & 66.7 \\
\hline 103 & 163 & 80 & 108 & 74.1 & 124 & 64.5 & 121 & 66.1 & 164 & 48.78 & 122 & 65.6 \\
\hline 104 & 74 & 47 & 81 & 58.0 & 95 & 49.5 & 89 & 52.8 & 109 & 43.12 & 78 & 60.3 \\
\hline 105 & 318 & 111 & 128 & 86.7 & 150 & 74.0 & 147 & 75.5 & 197 & 56.35 & 154 & 72.1 \\
\hline 106 & 291 & 113 & 137 & 82.5 & 175 & 64.6 & 171 & 66.1 & 215 & 52.56 & 164 & 68.9 \\
\hline 107 & 37 & 23 & 37 & 62.2 & 48 & 47.9 & 41 & 56.1 & 51 & 45.10 & 37 & 62.2 \\
\hline 111 & 147 & 85 & 134 & 63.4 & 162 & 52.5 & 157 & 54.1 & 193 & 44.04 & 139 & 61.2 \\
\hline 112 & 357 & 126 & 148 & 85.1 & 178 & 70.8 & 175 & 72.0 & 232 & 54.31 & 179 & 70.4 \\
\hline 113 & 503 & 171 & 198 & 86.4 & 245 & 69.8 & 242 & 70.7 & 314 & 54.46 & 243 & 70.4 \\
\hline 114 & 301 & 108 & 133 & 81.2 & 228 & 47.4 & 219 & 49.3 & 228 & 47.37 & 168 & 64.3 \\
\hline 115 & 1013 & 218 & 232 & 94.0 & 274 & 79.6 & 272 & 80.1 & 353 & 61.76 & 286 & 76.2 \\
\hline 116 & 136 & 77 & 120 & 64.2 & 152 & 50.7 & 146 & 52.7 & 175 & 44.00 & 126 & 61.1 \\
\hline 117 & 591 & 181 & 202 & 89.6 & 230 & 78.7 & 228 & 79.4 & 308 & 58.77 & 245 & 73.9 \\
\hline 122 & 145 & 88 & 140 & 62.9 & 161 & 54.7 & 156 & 56.4 & 196 & 44.90 & 142 & 62.0 \\
\hline 123 & 262 & 100 & 119 & 84.0 & 142 & 70.4 & 139 & 71.9 & 184 & 54.35 & 142 & 70.4 \\
\hline 124 & 714 & 186 & 202 & 92.1 & 231 & 80.5 & 230 & 80.9 & 307 & 60.59 & 247 & 75.3 \\
\hline 125 & 1577 & 248 & 256 & 96.9 & 294 & 84.4 & 292 & 84.9 & 366 & 67.76 & 307 & 80.8 \\
\hline 126 & 281 & 136 & 176 & 77.3 & 189 & 72.0 & 186 & 73.1 & 263 & 51.71 & 200 & 68.0 \\
\hline 127 & 727 & 217 & 242 & 89.7 & 284 & 76.4 & 282 & 77.0 & 368 & 58.97 & 293 & 74.1 \\
\hline 128 & 160 & 81 & 105 & 77.1 & 110 & 73.6 & 108 & 75.0 & 155 & 52.26 & 118 & 68.6 \\
\hline 133 & 349 & 136 & 167 & 81.4 & 235 & 57.9 & 229 & 59.4 & 267 & 50.94 & 202 & 67.3 \\
\hline 134 & 861 & 193 & 204 & 94.6 & 227 & 85.0 & 226 & 85.4 & 299 & 64.55 & 246 & 78.5 \\
\hline 135 & 1028 & 204 & 218 & 93.6 & 292 & 69.9 & 288 & 70.8 & 351 & 58.12 & 278 & 73.4 \\
\hline
\end{tabular}

\section{Discussion}

Ferns and lycophytes are the most threatened plant group in Brazilian Flora (Martinelli \& Moraes 2013). This threat has many causes, but one of them is habitat loss associated with low sampling efforts (Tedesco et al. 2014), especially before the accomplishment of two large surveys, namely the Illustrated Flora of Santa Catarina (Reitz 1965) and IFFSC (Vibrans et al. 2010). This kind of survey can dramatically increase the number of recorded species, which recently occurred in Minas Gerais and Espírito Santo (T.E. Almeida, personal communication). These surveys made Santa Catarina a region with an even distribution of samples for angiosperms (Sousa-Baena et al. 2014); for lycophytes and ferns, we here found areas with high sampling effort, but others with few collections.
The overall study area was well-sampled, as could be expected for a large study area with standardized sampling units (Jiménez-Valverde \& Hortal 2003; Rezende et al. 2014). When all data were analyzed together, we found 95\% (ACE), 93\% (C1), 88\% (C2), 87\% (J1) and 82\% (J2) of fit between estimated and predicted values, thereby indicating that Santa Catarina is well-sampled. However, all values were higher than those reported by List of Species of the Brazilian Flora (2014), which is of 448 species for Santa Catarina. This could be explained at least in part by a few records that we were not able to include in our database, such as those without a herbarium voucher, or because there are new species or records to be sampled. Within Santa Catarina Protected Areas, 4,012 samples and 296 species of lycophytes and ferns were recorded. Seven species were considered as vulnerable, one species was classified as critically endangered, and seven other 


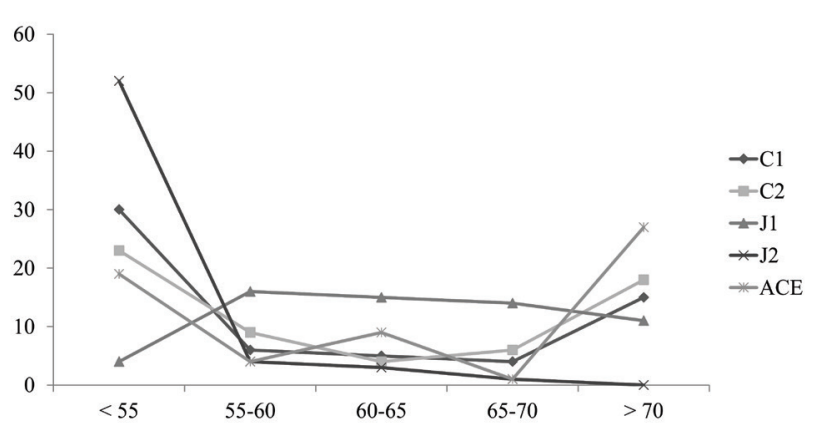

Figure 4. Distribution of $50 \times 50 \mathrm{~km}$ sample units in a sector of the Subtropical Atlantic Forest, Santa Catarina, Southern Brazil, in each interval and estimators ACE (ACE), Chao 1 (C1), Chao 2 (C2), Jackknife 1 (J1), and Jackknife 2 (J2).

Table 2. Number of $50 \mathrm{~km} \times 50 \mathrm{~km}$ sample units and the percentage of observed species in relation to the estimated number of species using different estimators in a sector of the Subtropical Atlantic Forest. ACE (ACE), Chao 1 (C1), Chao 2 (C2), Jackknife 1 (J1) and Jackknife 2 (J2).

\begin{tabular}{|l|c|c|c|c|c|}
\hline \% of observed $x$ estimated species & ACE & C1 & C2 & J1 & J2 \\
\hline$<55$ & 19 & 30 & 23 & 4 & 52 \\
\hline $\mathbf{5 5 - 6 0}$ & 4 & 6 & 9 & 16 & 4 \\
\hline $\mathbf{6 0 - 6 5}$ & 9 & 5 & 4 & 15 & 3 \\
\hline $\mathbf{6 5 - 7 0}$ & 1 & 4 & 6 & 14 & 1 \\
\hline $\mathbf{7 0}$ & 27 & 15 & 18 & 11 & 0 \\
\hline Total & 60 & 60 & 60 & 60 & 60 \\
\hline
\end{tabular}

species were categorized as presumed extinct (Gasper \& Salino 2015). No large protected area (greater than 20,000 hectares) was found in the central and west parts of the state; such areas are exactly those with few collections and low recorded species.

When we analysed each one of the SU, at least $34 \%$ (J1) of them were not well-sampled ( $<60 \%$ of accuracy). This demonstrates that, even in a state with a tradition of collecting, much remains to be done to achieve satisfactory values for lycophytes and ferns. The data provided by herbarium (the aforementioned institutions), in digital or other formats, are crucial because, together with environmental data, they can help in the delineation of range and species descriptions (MacDougall et al. 1998). This information about species distribution is crucial to exploration, use, and conservation (Mutke \& Barthlott 2005).

The different geographical areas have different sampling accuracy, but the coastal region was the most thoroughly collected one, followed by the plateau and western regions. Biased sampling occured in the Rainforest region, where the Floristic and Forest Inventory of Santa Catarina State
(IFFSC) collected epiphytes, a procedure not performed in other regions (Vibrans et al. 2010; Caglioni et al. 2012) with high sampling accuracy ( $>70 \%$ SU in dark gray). The same bias in coastal areas (where the Rainforest occurs) was observed for angiosperms by Sousa-Baena et al. (2014). This bias may also be related to the heterogeneity of these SU (Ferrer-Castán \& Vetaas 2005), since they cover montane coastal regions (Martinelli 2007), such as the Serra Geral, Serra do Mar, and their valleys (Klein 1980). Several authors indicated the importance of mountainous regions as areas of speciation (Kozak \& Wiens 2012) and a favorable microclimate for some species (Holttum 1938; Parris 1985; Jones et al. 2011) because of the higher humidity of the region (Nimer 1989); humidity was identified by Gasper et al. (2015) as one of the variables that influence the composition of lycophytes and ferns in Santa Catarina. Other variables are the presence of active botanists (MacDougall et al. 1998) and available botanical inventories (Ahrends et al. 2011).

Most of the sample units (SU) that achieved sample sufficiency are located near universities or protected areas. These areas with a large sample number are concentrated in Rainforest vegetation, like the Serra do Itajaí National Park and the Florianópolis region (capital of Santa Catarina), or in a Mixed Forest plateau region, where some SU are located within the São Joaquim National Park, with 170 species recorded. These areas are generally not easily accessible, at least in their core area. Specific field trips in these areas explain the numerous collections and species richness, unlike easily accessible areas, where the number of samples is low (as in SU 46,56, and 66), as it would not be attractive to large field expeditions, because of the low vegetation cover (Fig. 2). In these cases, the museum-effect (Nelson et al. 1990; MacDougall et al. 1998) appears to have had an important impact on some of the species-richest lycophyte and fern areas in Santa Catarina. The same bias in the coastal region was observed by Werneck et al. (2011), studying endemic angiosperm species of Atlantic Forest. These authors found that few grid cells were well-surveyed and that the species richness in each cell depended on the sampling effort.

Based on the aforementioned data, it is possible to calculate how many areas would need to be sampled to give researchers the ability to direct collection efforts. For example, it would probably be productive to sample at least the 20 SU that do not have a sufficiency above $60 \%$ and discover how much time would be required to achieve such value; in addition, the cost of the field surveys could be ascertained (Soberón \& Llorente 1993). Even in a wellsampled area where species are well-identified (which may assist in the extrapolation of data to be applied to poorly sampled areas), sampling inequalities can result in biased and partial descriptions of changes in biodiversity (Hortal et al. 2007).

It is essential to begin collecting in these areas since the 
forest cover is small and highly fragmented (Fundação SOS Mata Atlântica \& Instituto Nacional de Pesquisas Espaciais 2009; Vibrans et al. 2013). The rates of forest-cover loss are growing in Santa Catarina (Fundação SOS Mata Atlântica \& Instituto Nacional de Pesquisas Espaciais 2009), which directly affects the sampling accuracy found in the state and probably results in species loss (Tedesco et al. 2014). Rodríguez-Loinaz et al. (2011) showed that fragmentation had a negative effect on the species richness and diversity, especially for ferns. Despite the fact that the number of endemic species was very low (five), the number of uniques was quite high (66). Considering this information, additional efforts should be taken to reduce the number of "rare" species (unicates or singletons), since the higher the number of unicates persisting in the data, the higher the chance that the total species richness has not been reached (Walther \& Moore 2005).

We believe that, due the fact that at least $34 \%$ of SU did not exhibit an accurate sampling effort, the opportunity to assess the whole of the natural vegetation and its diversity is diminishing. In view of the several studies mentioned, species diversity could have been underestimated not only in Santa Catarina, but across Brazil. Even areas previously considered as well-sampled may actually be undersampled, as demonstrated by Anthelme et al. (2011). Therefore, additional sampling effort should be directed towards areas that have not yet reached a minimum value of sampling intensity, here indicated to be between $60-70 \%$ for a subtropical zone, in order to improve the floristic sufficiency in each area (in the present case, for lycophytes and ferns), increasing precision and accuracy, and reducing the sampling bias (for further discussion, see Walther \& Moore 2005). Well-sampled areas can still contain surprises, such as new records recently documented in certain protected areas (Funez \& Gasper 2014), and therefore should not be ignored.

Our study demonstrates the relevance of this approach for conservation of biodiversity, especially in regard to lycophytes and ferns, and might be seen as an additional warning tool in the process of moving towards more accurate sampling. We believe it is necessary to address these points for conservation purposes, since the state of Santa Catarina is a region with one of the greatest rates of loss of forest coverage in Brazil (Fundação SOS Mata Atlântica \& Instituto Nacional de Pesquisas Espaciais 2009), and its forests are highly degraded and fragmented (Vibrans et al. 2013). Recent deforestation has expanded pastures, agricultural production, and plantations of exotic species, such as pine and eucalyptus, for timber and cellulose. Moreover, addressing these issues may be relevant not only for the state of Santa Catarina, but for the entire Subtropical Atlantic Forest. This study could call attention to the need to improve collection efforts before permanently losing lycophyte and fern biodiversity in the Subtropical Atlantic Forest, indeed even in other ecosystems outside Brazil.

\section{Acknowledgments}

The authors thank the Universidade Regional de Blumenau (FURB), Universidade Federal de Minas Gerais (UFMG), CNPq (Conselho Nacional de Desenvolvimento Científico e Tecnológico), and CAPES (Coordenação de Aperfeiçoamento de Pessoal de Nível Superior) for financial support. Additionally, the authors acknowledge CNPq for the productivity grants contributed to AS. AG also offers thanks to FUMDES for current grants. We also thanks Alan Smith for the English review.

\section{References}

Ahrends A, Burgess ND, Gereau RE, et al. 2011. Funding begets biodiversity. Diversity and Distributions 17: 191-200.

Anthelme F, Abdoulkader A, Viane R. 2011. Are ferns in arid environments underestimated? Contribution from the Saharan Mountains Journal of Arid Environments 75: 516-523.

Barbault R. 2011. A new beginning for biodiversity? Comptes Rendus Biologies 334: 483-8.

Butchart SHM, Walpole M, Collen B, et al. 2010. Global biodiversity: indicators of recent declines. Science 328: 1164-8.

Caglioni E, Bonnet A, Schmitt JL, et al. 2012. Epífitos vasculares predominantes em zonas ecológicas de forófitos, Santa Catarina, Brasil. Revista de Estudos Ambientais 14: 28-42.

Chao A. 1984. Nonparametric estimation of the number of classes in a population. Scandinavian Journal of Statistics 11: 265-270.

Chao A, Lee SM. 1992. Estimating the number of classes via sample coverage. Journal of the American Statistical Association 87: 210-217.

Chiarucci A, Enright NJ, Perry GLW, et al. 2003. Performance of nonparametric species richness estimators in a high diversity plant community. Diversity and Distributions 9: 283-295.

Colwell RK. 2013. EstimateS: statistical estimation of species richness and shared species from samples. Version 8. User's Guide and ap- plication. http://viceroy.eeb.uconn.edu/estimates Dec 2014.

Colwell RK, Coddington JA. 1994. Estimating terrestrial biodiversity through extrapolation. Philosophical Transactions of the Royal Society of London. Series B, Biological sciences 345: 101-118.

Condon M, Scheffer SJ, Lewis ML, Swensen SM. 2008. Hidden neotropical diversity: greater than the sum of its parts. Science 320: 928-931.

CRIA - Centro de Referência em Informação Ambiental. 2015. SpeciesLink. <http://www.cria.org.br/>. 01 May 2015.

ESRI - Environmental Systems Research Institute. 2011. ArcGIS Desktop: Release 10. Redlands, ESRI.

Feeley KJ, Silman MR. 2011. The data void in modeling current and future distributions of tropical species. Global Change Biology 17: 626-630.

Ferrer-Castán D, Vetaas OR. 2005. Pteridophyte richness, climate and topography in the Iberian Peninsula: comparing spatial and nonspatial models of richness patterns. Global Ecology and Biogeography 14:155165.

Forzza RC, Baumgratz JFA, Bicudo CEM, et al. 2012. New Brazilian floristic list highlights conservation challenges. Bioscience 62: 39-45.

Fundação SOS Mata Atlântica, Instituto Nacional de Pesquisas Espaciais. 2009. Atlas dos remanescentes florestais da Mata Atlântica período 2005-2008. São Paulo, SOS Mata Atlântica/INPE.

Funez LA, Gasper AL. 2014. Parque Nacional da Serra do Itajaí (southern Brazil) shrub and herbs flora. Check List 10: 1249-1259.

Gasper AL, Eisenlohr PV, Salino A. 2015 Climate-related variables and geographic distance affect fern species composition across a vegetation gradient in a shrinking hotspot. Plant Ecology \& Diversity 8: 25-35.

Gasper AL, Salino A, Vibrans AC, et al. 2012. Pteridófitas de Santa Catarina, um olhar sobre os dados do Inventário Florístico Florestal de Santa Catarina, Brasil. Acta Botanica Brasilica 26: 421-434. 
Gasper AL, Salino A. 2015. Samambaias e licófitas de Santa Catarina: composição, riqueza e espécies ameaçadas. Iheringia, ser. Botanica 70: 321-342

Heck Jr KL, Belle G, Simberloff D. 1975. Explicit calculation of the rarefaction diversity measurement and the determination of sufficient sample size. Ecology 56: 1459-1461.

Hijmans RJ, Guarino L, Bussink C, et al. 2005. DIVA-GIS. v7.5. A geographic information system for the analysis of species distribution data. <http://www.diva-gis.org> 15 Jan. 2015.

Holttum RE. 1938. The ecology of tropical Pteridophytes. Manual of Pteridology SE - 13: 420-450.

Hortal J, Jiménez-Valverde A, Gómez JF, Lobo JM, Baselga A. 2008. Historical bias in biodiversity inventories affects the observed environmental niche of the species. Oikos 117: 847-858.

Hortal J, Lobo JM, Jiménez-Valverde A. 2007. Limitations of biodiversity databases: case study on seed-plant diversity in Tenerife, Canary Islands. Conservation Biology 21: 853-63.

IBGE - Instituto Brasileiro de Geografia e Estatística. 1992. Manual técnico da vegetação brasileira. Rio de Janeiro, Ministério do Planejamento, Orçamento e Gestão.

Jiménez-Valverde A, Hortal J. 2003. Las curvas de acumulación de especies y la necesidad de evaluar la callidad de los inventario biológicos. Revista Iberica de Aracnologia 8: 151-161.

Jones MM, Szyska B, Kessler M. 2011. Microhabitat partitioning promotes plant diversity in a tropical montane forest. Global Ecology and Biogeography 20: 558-569.

Kim KC, Byrne LB. 2006. Biodiversity loss and the taxonomic bottleneck: emerging biodiversity science. Ecological Research 21: 794-810.

Klein RM. 1980. Ecologia da flora e vegetação do Vale do Itajaí (continuação). Sellowia 32: 165-389.

Klein RM. 1984. Aspectos dinâmicos da vegetação do Sul do Brasil. Sellowia 36: 5-54.

Kozak K, Wiens JJ. 2012. Phylogeny, ecology, and the origins of climaterichness relationships. Ecology 93: 167-181.

Lewinsohn TM, Prado PI. 2005. Quantas espécies há no Brasil? Megadiversidade 1: 36-42.

List of Species of the Brazilian Flora. 2014. <http://floradobrasil.jbrj.gov. br>. 01 Aug. 2012.

Lughadha EM. 2004. Towards a working list of all known plant species. Philosophical Transactions of the Royal Society of London. Series B, Biological sciences 359: 681-687.

MacDougall AS, Loo JA, Clayden SR, Goltz JG, Hinds HR. 1998. Defining conservation priorities for plant taxa in southeastern New Brunswick, Canada using herbarium records. Biological Conservation 86: 325-338.

Maldonado C, Molina CI, Zizka A, et al. 2015. Estimating species diversity and distribution in the era of Big Data: to what extent can we trust public databases? Global Ecology and Biogeography 24: 973-984.

Martinelli G, Moraes MA. 2013. Livro vermelho da flora do Brasil. Rio de Janeiro, Instituto de Pesquisas Jardim Botânico do Rio de Janeiro.

Martinelli G. 2007. Mountain biodiversity in Brazil. Revista Brasileira de Botânica 30: 587-597.

May RMC. 2011. Why should we be concerned about loss of biodiversity. Comptes Rendus Biologies 334: 346-350.

Murphy GEP, Romanuk TN. 2014. A meta-analysis of declines in local species richness from human disturbances. Ecology and Evolution 4: 91-103.

Mutke J, Barthlott W. 2005. Patterns of vascular plant diversity at continental to global scales. Biologiske Skrifter 55: 521-531.

Nelson BW, Ferreira CAC, Silva MF, Kawasaki ML. 1990. Endemism centres, refugia and botanical collection density in Brazilian Amazonia. Nature 345: 714-716.

Nimer E. 1989. Climatologia do Brasil. 2nd. edn. Rio de Janeiro, IBGE.

Oliveira-Filho AT. 2009. Classificação das fitofisionomias da América do Sul cisandina tropical e subtropical: proposta de um novo sistema - prático e flexível - ou uma injeção a mais de caos. Rodriguésia 60: 237-258.

Pandit MK, Sodhi NS, Koh LP, Bhaskar A, Brook BW. 2007. Unreported yet massive deforestation driving loss of endemic biodiversity in Indian Himalaya. Conservation 16: 153-163.
Parris BS. 1985. Ecological aspects off distribution and speciation in OldWorld tropical ferns. Proceedings of the Royal Society of London. Series B, Biological Sciences 86: 341-346.

Pyke GH, Ehrlich PR. 2010. Biological collections and ecological/ environmental research: a review, some observations and a look to the future. Biological Reviews 85: 247-266.

Reitz R. 1965. Plano de coleção. Flora Ilustrada Catarinense. Itajaí, Herbário Barbosa Rodrigues.

Rezende VL, Eisenlohr PV, Gasper AL, Vibrans AC, Oliveira-Filho AT. 2014 Toward a better understanding of the subtropical Atlantic Forest in the state of Santa Catarina, Brazil: tree sampling accuracy, species richness and frequency of rare species. Acta Botanica Brasilica 28: 382-391.

Rezende VL, Oliveira-Filho AT, Eisenlohr PV, Kamino LHY, Vibrans AC. 2015. Restricted geographic distribution of tree species calls for urgent conservation efforts in the Subtropical Atlantic Forest. Biodiversity and Conservation 24: 1057-1071.

Ribeiro MC, Martensen AC, Metzger JP, Tabarelli M, Scarano F, Fortin MJ. 2011. The Brazilian Atlantic Forest: a shrinking biodiversity hotspot. In: Zachos FE, Habel JC. (eds.) Biodiversity Hotspots. Berlin, Springer Berlin Heidelberg. p. 405-434.

Rodríguez-Loinaz G, Amezaga I, Onaindia M. 2011. Does forest fragmentation affect the same way all growth-forms? Journal of Environmental Management 94: 125-131.

Salino A, Almeida TE. 2009. Pteridófitas. In: Stehmann JR, Forzza RC, Salino A, Sobral M, Costa DP, Kamino LHY. (eds.) Plantas da Floresta Atlântica. Rio de Janeiro, Instituto de Pesquisas Jardim Botânico do Rio de Janeiro. p. 19-25.

Sánchez-Fernández D, Lobo JM, Abellán P, Ribera I, Millán A. 2008. Bias in freshwater biodiversity sampling: the case of Iberian water beetles. Diversity and Distributions 14: 754-762.

Sastre P, Lobo J. 2009. Taxonomist survey biases and the unveiling of biodiversity patterns. Biological Conservation 142: 462-467.

Silva IAA, Pereira AFN, Barros ICL. 2014. Fragmentation and loss of habitat: consequences for the fern communities in Atlantic forest remnants in Alagoas, north-eastern Brazil. Plant Ecology \& Diversity 7: 509-517.

Sloan S, Jenkins CN, Joppa LN, Gaveau DLA, Laurance WF. 2014. Remaining natural vegetation in the global biodiversity hotspots. Biological Conservation 177: 12-24.

Soberón J, Llorente J. 1993. The use of species accumulation functions for the prediction of species richness. Conservation Biology 7: 480-488.

Sousa-Baena MS, Garcia LC, Peterson AT. 2014. Completeness of digital accessible knowledge of the plants of Brazil and priorities for survey and inventory. Diversity and Distributions 20: 369-381.

Tedesco PA, Bigorne R, Bogan AE, Giam X, Jézéquel C, Hugueny B. 2014. Estimating how many undescribed species have gone extinct. Conservation Biology 28: 1360-1370.

Thiers B. 2015. Index Herbariorum: a global directory of public herbaria and associated staff. New York Botanical Garden's Virtual Herbarium. <http://sweetgum.nybg.org/science/ih/>. 04 Nov. 2015.

Urban MC. 2015. Accelerating extinction risk from climate change. Science 348: 571-573.

Vibrans AC, McRoberts RE, Moser P, Nicoletti AL. 2013. Using satellite image-based maps and ground inventory data to estimate the area of the remaining Atlantic forest in the Brazilian state of Santa Catarina. Remote Sensing of Environment 130: 87-95.

Vibrans AC, Sevegnani L, Lingner DV, Gasper AL, Sabbagh S. 2010. Inventário florístico florestal de Santa Catarina (IFFSC): aspectos metodológicos e operacionais. Pesquisa Florestal Brasileira 30: 291302.

Walther BA, Moore JL. 2005. The concepts of bias, precision and accuracy, and their use in testing the performance of species richness estimators, with a literature review of estimator performance. Ecography 28: 815-829.

Werneck MS, Sobral M, Rocha CTV, Landau EC. 2011. Distribution and Endemism of Angiosperms in the Atlantic Forest. Natureza \& Conservação 9: 188-193.

Zuloaga FO, Morrone O, Belgrano MJ. 2008. Catálogo de plantas vasculares del Cono Sur- Volúmen 1- Pteridophyta, Gymnospermae, Monocotyledoneae. New York, Missouri Botanical Garden. 